\title{
SELECTION OF ANALYTICAL COMPUTATIONAL MODEL OF CONTACT PRESSURE
}

\section{ONDŘEJ MARŠÁLEK, JAN VOPAŘIL, PETER RAFFAI, PAVEL NOVOTNÝ}

Institute of Automotive Engineering, Brno University of Technology; Technická 2, CZ 61669 Brno, Czech Republic Tel.: +420 541143 476, Fax: +420 541143 354, Email: marsalek@fme.vutbr.cz

\section{SHRNUTí}

Tento článek popisuje porovnání dvou výpočetních metod pro stanovování kontaktního tlaku mezi dvojicí skutečných drsných povrchů: výpočet založený na MKP (Metoda Konečných Prvků), využívající komerční softwarový nástroj ANSYS, a výpočet založený na MKD (Metoda Konečných Diferencí), využívající analytické funkce implementované v programovacím prostředí MATLAB. Toto porovnání později vede $k$ výběru nejvhodnějšího analytického kontaktního modelu použitelného pro časově efektivní a přesné stanovování kontaktního tlaku. Data o površích jsou pro numerické simulace získávány pomocí optické profilometrie. Popis tvorby 3D MKP modelů drsných povrchů je uveden v tomto článku. Dále tento článek popisuje veškerou problematiku spojenou s konvergencí těchto simulací a důležité zpracování výsledků MKP simulací spolu s jejich porovnáním s výsledky získanými z uživatelsky vytvářených funkcí v programovacím prostředí MATLAB.

\section{KLÍČOVÁ SLOVA: MKP, MKD, KONTAKTNÍ TLAK, PROLNUTÍ POVRCHŮ, DRSNOST POVRCHU}

\section{ABSTRACT}

This paper presents a comparison of two contact pressure calculation methods between two real rough surfaces: a calculation based on FEM (Finite Element Method) using commercial software tool ANSYS and a calculation based on FDM (Finite Difference Method) using analytical functions implemented in programing tool MATLAB. This comparison, lately, leads to the selection of the most appropriate analytical contact model useful for time-effective and precise contact pressure determination. Surface data for numerical simulations are obtained by optical profilometry. For the case of the modelling process of 3D FEM models of rough surfaces the description of their building is included in this article. Furthermore, this paper discusses all challenges connected with the convergence of such simulations and essential post-processing of FEM simulation results, together with their comparison, along the results obtained by user-written MATLAB functions.

KEYWORDS: FEM, FDM, CONTACT PRESSURE, SURFACE DEFLECTION, ROUGH SURFACE

\section{INTRODUCTION}

One of the main questions of any computational modelling is still a compromise between time efficiency and the accuracy of results. For the purpose of making a time-efficient and at the same time sufficiently accurate computational software tool for the detailed analysis of contact pairs, the most appropriate analytical model for determining the contact pressure between two rough surfaces had to be chosen.

The aforementioned accuracy of results is influenced also by the degree of capturing of the physical essence of the problem. Evaluation of this accuracy can be assessed on the basis of concordance between the results of numerical simulations and experiments. Generally, two possible ways are available for results verification (or for code fine-tuning): first, commercially available software tools which, although they do not address the issues in such detail as it is required nowadays, can at least provide information regarding the nature and trend of the expected partial results; second, experimental validation of the computational simulations.

Because the experimental verification of contact pressure in the scale of surface roughness of real machinery parts is, even nowadays, very challenging the option of usage of the probably most sophisticated and well known commercially available software tool -ANSYS - was chosen and described in this paper. Introduction of each analytical relation, description of development process of FEM model of rough surfaces and all challenges associated with it, are described in the following sections. 
Data characterising both surfaces (piston skirt and piston liner) were acquired from the optical profilometry. The surface pattern of each machinery part was scanned on ten spots. Resulting value of contact pressure from each contact model (or from the FEM simulation) is an average value of all ten surface pattern examples.

\section{ANALYTICAL MODELS}

In this chapter all the contact models are presented step-bystep, which were taken into account in the developed complex algorithm for detailed analysis of rough surfaces.

\subsection{CONTACT MODEL GREENWOOD \& TRIPP}

The contact model Greenwood \& Tripp [1] is very timeeffective, relatively user-friendly, and therefore, is still in use. This computational model was published in 1970 and its basic equation for the contact pressure calculation has a form of:

$p_{c}(h)=\frac{8 \pi}{5}\left(\eta_{r} \beta \sigma\right) K F_{5 / 2}\left(\frac{h}{\sigma}\right)$.

Where:

$$
\begin{aligned}
& K=\frac{2 \sqrt{2}}{3}\left(\eta_{r} \beta \sigma\right) E^{\prime} \sqrt{\left(\frac{\sigma}{\beta}\right)}, \\
& \sigma=\sqrt{S q_{1}^{2}+S q_{2}^{2}}, \\
& \frac{1}{E^{\prime}}=\frac{1-v_{1}^{2}}{E_{1}}+\frac{1-v_{2}^{2}}{E_{2}} .
\end{aligned}
$$

Where $\eta_{r}$ is the surface density of roughness peaks $\left[\mathrm{m}^{-2}\right], h$ is the oil film height (distance between mean planes of 3D rough surface profiles) $[\mathrm{m}], \beta$ is the average radius of curvature of rough surface asperities [m], $\sigma$ is the combined RMS of both surfaces [m], $v$ is the Poisson's ratio [-], $S q$ is the RMS of a 3D rough profile $[\mathrm{m}], E^{\prime}$ is the combined Young's modulus [Pa], $E_{1(2)}$ is the Young's modulus for each material of the contact pair [Pa] and $F_{5 / 2}$ is the function of contact pressure increase [-]. Function $F_{5 / 2}(h / \sigma)$ is in the original information source [1] defined only for values of $(h / \sigma)$ ratio in the range between 0 and 4 . For values of $(h / \sigma)$ ratio higher than 4 the situation is not difficult. In these cases function $F_{5 / 2}(h / \sigma)$ has zero values (the surfaces are separated enough from each other so no contact is present), and therefore, the contact pressure is zero, too. In the case when the EHD approach is not considered, the $(h / \sigma)$ ratio could decrease below the value of 0 (penetration of contact surfaces). Therefore, also this situation has to be on the safe side considering the numerical solution. Function $F_{5 / 2}(h / \sigma)$ is then from the point $(h / \sigma)=0$ tangentially extrapolated by a linear function. Equation describing this situation has the following shape:

$F_{5 / 2}(h / \sigma)=-0.99888 \cdot(h / \sigma)+\operatorname{Coef}(9)$,

Where $\operatorname{Coef}(9)$ is the $9^{\text {th }}$ polynomial coefficient of Taylor series created for the data from the table which is listed in the source [1].

\subsection{CONTACT MODEL HERTZ}

The contact model Hertz [2] is probably the most widely known and most widely used contact model. Accepted simplifying assumptions (taken from source [2]) are: contact bodies are considered isotropic, elastic and perfectly smooth. The contact area is considered small and flat in comparison with radius of curvature of undeformed contact bodies.

In the case of analysis of contact of two 3D rough surfaces it seems to be convenient to replace the real shape of surfaces asperities with the ideally spherical shape. The Hertzian pressure is then solved as a contact of two spherical bodies. The contact force $W[\mathrm{~N}]$ is calculated as:

$$
W=\sqrt{\frac{\delta_{R}^{3} E^{\prime 2} R^{\prime}}{1.0397^{3}}} .
$$

Here $\delta_{R}$ is the deflection (penetration) of surfaces [m], $E^{c}$ is the combined Young's modulus [Pa] and $R^{c}$ is the combined radius of curvature $[\mathrm{m}]$. The radius of contact area $a[\mathrm{~m}]$ is given by the equation:

$$
a=\left(\frac{3 W R^{\prime}}{E^{\prime}}\right)^{1 / 3} \text {. }
$$

Equations for the determination of maximal $\left(P_{\max }\right)$ and average $\left(P_{a v}\right)$ contact pressure $[\mathrm{Pa}]$ follows.

$P_{\max }=\frac{3 W}{2 \pi a^{2}}, P_{a v}=\frac{W}{\pi a^{2}}$.

Input variables for this contact model are then the deflection (penetration) of contact bodies $\delta_{R}[\mathrm{~m}]$, the material characteristic Young's modulus $E^{c}[\mathrm{~Pa}]$ and the combined radius of curvature $R^{\prime}[\mathrm{m}]$. 
For all contact models (except the model Grenwood \& Tripp) an identical way of combined radius of rough surfaces curvature calculation is used. This calculation is based on the determination of the osculation circle's radius. This radius of curvature is determined for each point of surface rough profile in both directions $(x$ and $y$ ). Radius of curvature of contact body 1 in the direction $x$ is given by the equation:

$R_{1 x}=\frac{\left(1+\left(z^{\prime}(x)\right)^{2}\right)^{3 / 2}}{z^{\prime \prime}(x)}$.

\subsection{CONTACT MODEL LAGEMANN}

Volker Lagemann in his dissertation [3] published slightly modified equations for Hertzian pressure calculation. For completeness, these equations were implemented as another option for the calculation of the contact pressure, and to illustrate that also equations for Hertzian pressure calculation can have several modifications.

$P_{\max }=\frac{1}{\pi} \sqrt{\frac{6 E^{\prime 2} W}{R^{\prime 2}}}$

The combined Young's modulus and the combined (reduced) radius of curvature of contact bodies are described by identical formulae, as in the case of the above mentioned Hertzian contact model. Radius of the contact area $a[\mathrm{~m}]$ is calculated differently. This calculation is governed by the following formula:

$a=\left(\frac{3 W R^{\prime}}{4 E^{\prime}}\right)^{1 / 3}$.

The normally acting contact force $W[\mathrm{~N}]$ is also calculated according to a different formula:

$W=\sqrt{\frac{16 \delta_{R}^{3} E^{\prime 2} R^{\prime}}{9}}$.

The average contact pressure $P_{a v}[\mathrm{~Pa}]$ is then given by the penetration of the surfaces:

$P_{a v}=P_{\max } \sqrt{1+\frac{\delta_{R}{ }^{2}}{a^{2}}}$

\subsection{CONTACT MODEL PASARIBU \& SHIPPER}

This computational model [4] takes into consideration all three possible states of material behaviour - fully elastic, elastoplastic, and fully plastic behaviour. When compared to all previous models, only one extra variable is added - hardness of the softer material. Transitions between the individual material behaviours are controlled by the depth of the penetration. Boundary values of penetration (deflection) $\left(\omega_{c}[-]\right)$ are given by the following equations:

$\omega_{c 1}=0.89 R^{\prime}\left(\frac{H}{E^{\prime}}\right)$,

$\omega_{c 2}=54 \omega_{c 1}$.

The contact behaves elastically when the condition of $\delta_{R}<$ $\omega_{c l}$ is met. The elasto-plastic behaviour of the contact pair is considered in the case when the condition of $\omega_{c 1}<\delta_{R}<\omega_{c 2}$ is valid. And finally - the condition for fully plastic behaviour is given by the relation $\omega_{c 2}<\delta_{R}$.

In the case of fully elastic behaviour the calculation is governed by the formulae:

$A_{e l}=\pi R^{\prime} \delta_{R}$

$F_{e l}=\frac{4}{3} E^{\prime} R^{0.5} \delta_{R}^{1.5}$

If materials are in the region of elasto-plastic behaviour (the second condition is met) the calculation uses the following formulae:

$A_{e p}=\pi R^{\prime} \delta_{R}\left[1-2\left(\frac{\delta_{R}-\omega_{c 1}}{\omega_{c 2}-\omega_{c 1}}\right)^{3}+3\left(\frac{\delta_{R}-\omega_{c 1}}{\omega_{c 2}-\omega_{c 1}}\right)^{2}\right\rceil$,

$F_{e p}=\left[H-0.6 H \frac{\ln \omega_{c 2}-\ln \delta_{R}}{\ln \omega_{c 2}-\ln \omega_{c 1}}\right] A_{e p}$

And finally - equations describing the fully plastic behaviour of the contact pair have the following shape:

$A_{p}=2 \pi R^{\prime} \delta_{R}$,

$F_{p}=H A_{p}$

Here $A_{e l^{\prime}} A_{e p}$ and $A_{p}$ are contact areas $\left[\mathrm{m}^{2}\right]$ for given material states, $H$ is the hardness of the softer material $[\mathrm{Pa}]$, and $F_{e l} F_{e p}$ a $F_{p}$ are contact forces [N].

The integral contact pressure in all described cases is calculated as the sum of contact forces applied on the area of the analysed surface element. 


\section{FINITE ELEMENT MODELLING}

The experimental validation of contact pressure calculation is very complicated. Taking into consideration the need to choose from analytical contact models a methodology was suggested based on the possibility to use the commercially available, wellknown software tool ANSYS.

The only input for the Finite Element Method (FEM) modelling were matrixes of values describing roughness in one axis (height) and values indicating the distance between individual points (distance). The number of these points varied depending on the type of task the model was subjected to. In cases of testing of different parameters setup, a grid with fewer points ( $50 \times 50)$ was sufficient to be modelled, but in the final calculations grids with a higher number of points were used (400x400) for greater accuracy; see Figure 1.

\subsection{MATERIAL MODEL}

Different material types (material properties) were set for each body with surface roughness, but the same material
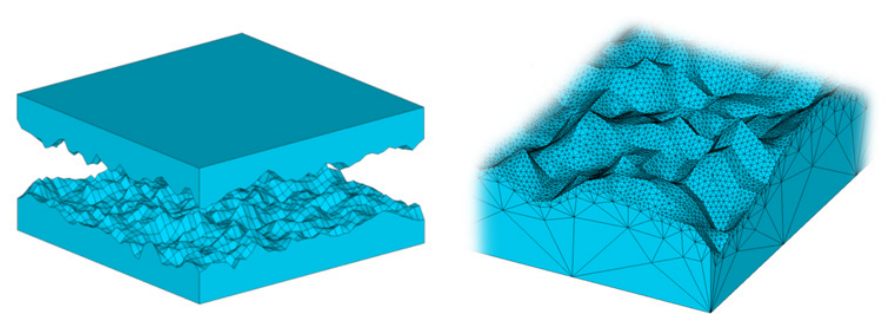

FIGURE 1: Variable element size of the FEM model of rough surfaces OBRÁZEK 1: Proměnná velikost elementů MKP modelu drsných povrchů model was used for both: multilinear isotropic hardening. Multilinear model was necessary for better capturing of the stress-strain curve, especially in areas with a larger deformation where the stress-strain curve is approximated by horizontal line. Isotropic model was chosen because of its better tendency towards convergence, even if from the theoretical premises point of view for roles with higher values of nodes displacement a kinematic hardening model would be more suitable.

\subsection{BOUNDARY CONDITIONS}

All six degrees of freedom were removed from the bottom surface of the body below to prevent any displacement and rotation.

The side walls of the bodies can only move in z-axis direction and also rotate. This setting should correspond to the fact that in reality these bodies are only partial elements of different components and their sides are in reality attached to another material.

\subsection{LOADING STATE}

Pushing the surfaces against each other was simulated by moving the upper side of one of the bodies towards the other, see the following figure.

For each computed surface about twenty loading states were simulated with different distances from the zero planes. It enabled a sufficiently accurate evaluation of the behaviour of the roughened surfaces with different degrees of deformation of individual peaks of roughness; see Figure 2 .

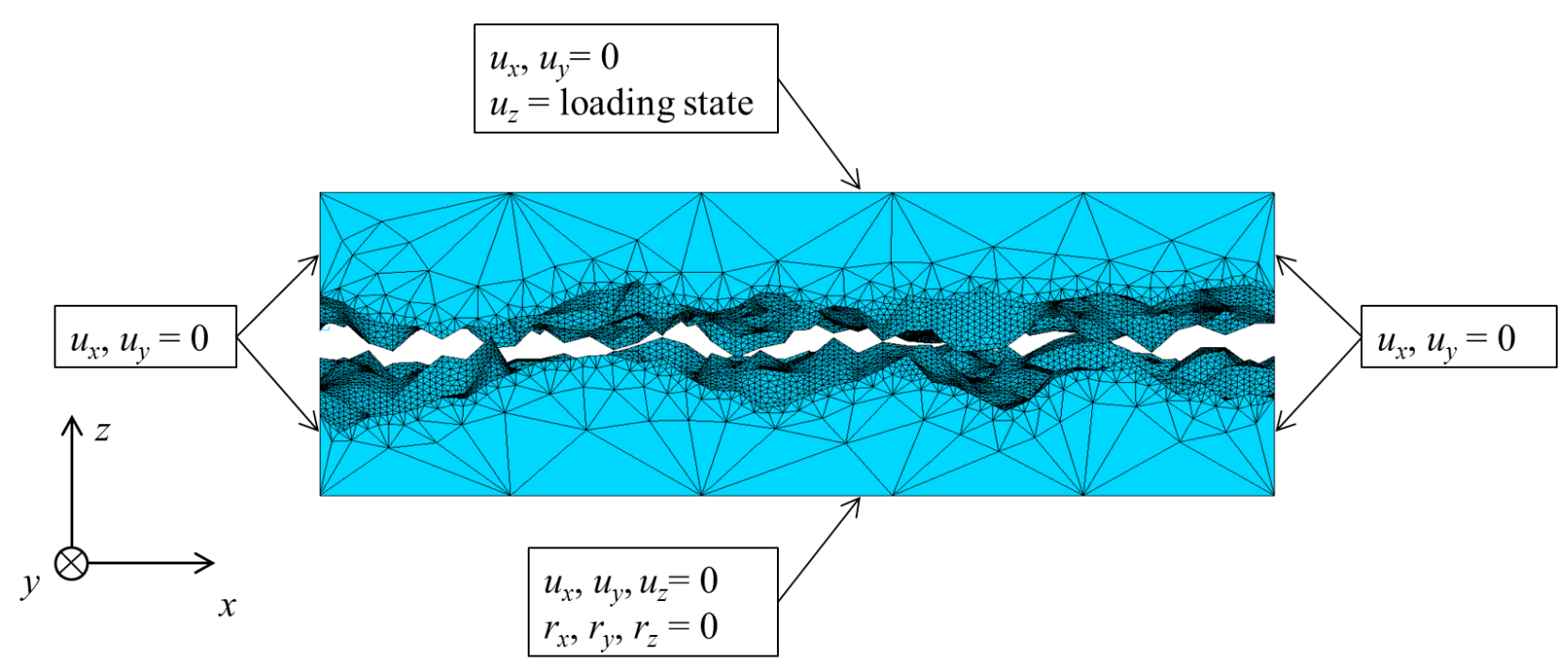

FIGURE 2: Applied boundary conditions

OBRÁZEK 2: Aplikované okrajové podmínky 


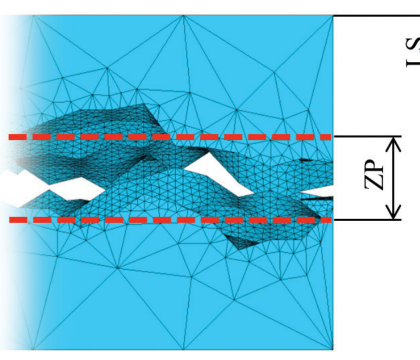

UNLOADED

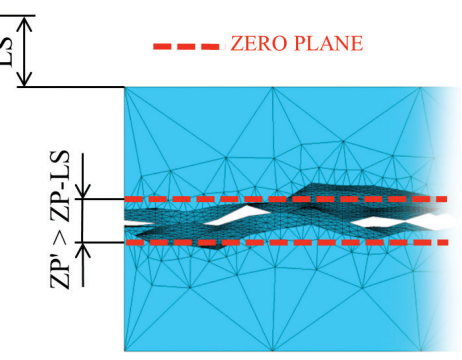

LOADED
FIGURE 3: Volume deformations corrections

OBRÁZEK 3: Korekce objemových deformací

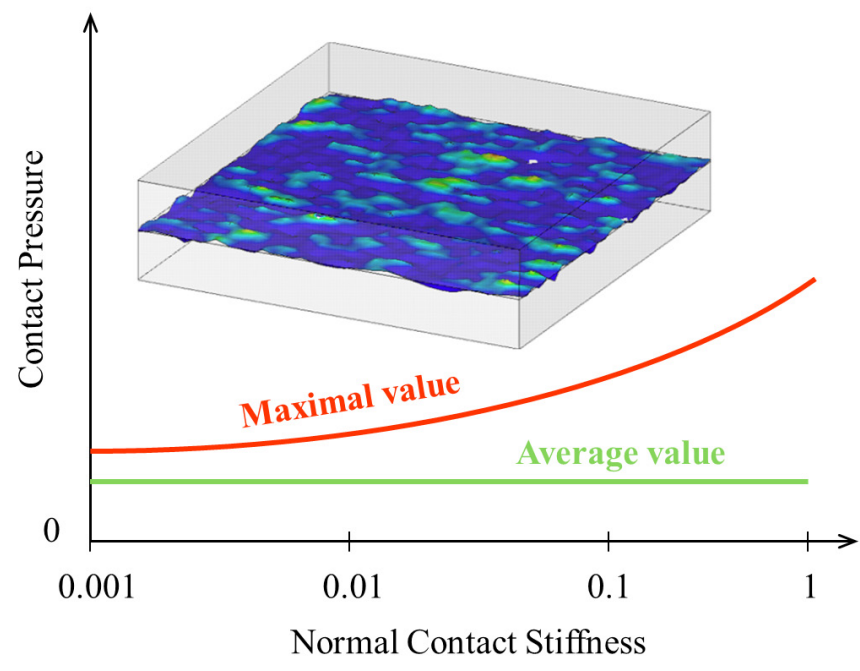

FIGURE 4: Normal contact stiffness

OBRÁZEK 4: Kontaktní tuhost v normálovém směru

\subsection{CORRECTIONS OF VOLUME DEFORMATIONS}

The loading state for comparison with the analytical computational method was defined as the distance between zero planes of roughened surfaces. Zero plane is defined as a reference plane where the mean average height of all surface roughness asperities is equal to zero.

This loading state could not be adjusted precisely in the FEM solver because the displacement conditions placed directly on the rough surface prevented any further calculation. Setting of the loading state by shifting the lower edge of the model was problematic because it brought up the problem of the whole body model compression into the calculation. Therefore, corrections were necessary.

Corrections were calculated from the deformation of all nodes of the rough surface mesh. Each correction was calculated as the difference between the zero plane distance (load state parameter) and resulting node-shift after load application. Results from the FEM computational model were then combined with the results from the analytical model with the same distance of zero planes after application of load; see Figure 3.

\subsection{CONVERGEN CE CHALLENGES}

The calculation of contact problem of real rough surfaces proved to be very problematic in terms of convergence. The reason is that the individual gradients of roughness' peaks are relatively steep and are in contact with the opposite surface only on a very small area. Load state is, therefore, composed of many "point load" states. This way the loading itself is usually referred to as divergent.

One of the most important variables influencing the convergence is contact stiffness. Greater values of normal contact stiffness reduce the penetration and thus the numerical solution approximates more precisely to the real state of the loading. On the other hand, the higher the normal contact stiffness the more convergence difficulties appear. In case of convergence troubles it is necessary to decrease the contact stiffness which leads to greater penetration distance, i.e. fictional loading state situations; and therefore, to inaccurate results. These inaccurate results appear especially in areas with maximum pressure values, i.e. in our case in nodes with point loading state and its immediate vicinity. In terms of physical principles a balance of both bodies must be achieved. The sum of total contact pressures at all contact nodes is always the same, regardless of contact stiffness. That is why the more extensive areas of roughness surface were compared with the analytical model, not only the results in single points. The presence of at least several local minimums and maximums was the condition for the comparison process; see Figure 4.

\section{RESULTS DISCUSSION}

The closest to the results of FEM analysis is the model by authors Pasaribu \& Shipper. This computational model considers all possible states of material behaviour, as well as the FEM model does in ANSYS. The hardness of the softer material is in this case an essential variable.

On the other hand, the computational model by Greenwood $\&$ Tripp gives the lowest values of contact pressures. For this reason, plotting the values had to be multiplied by 10 . The reason is the deviation of the parameter $(\eta, \beta \sigma)$ which should be, based on information source [1], in the range between 0.03 and 0.05 . If the tested surfaces are not within this range, biased results can be expected.

Computational algorithms by Hertz and Lagemann were printed to the minor axis of the graph because of completely different (higher) results. This behaviour of these two computational models is described also in information source [3]. Computational models Lagemann and Hertz give relatively similar values of contact pressures, which is logical, since both approaches are based on the Hertz theory; see Figure 5. 


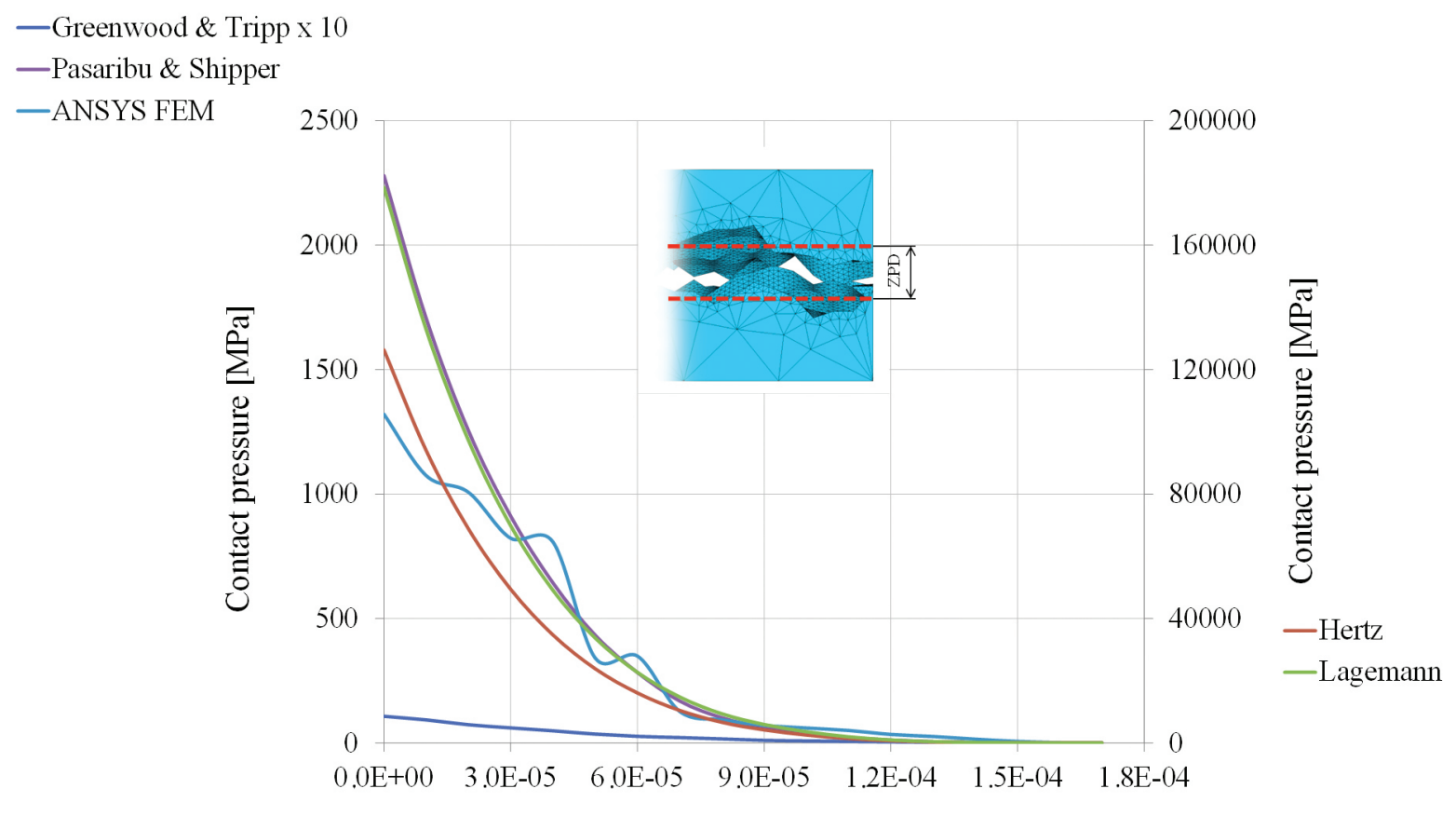

Zero planes distance $[\mathrm{mm}]$

FIGURE 5: Comparison of results

OBRÁZEK 5: Porovnání výsledků

\section{CONCLUSION}

The intention of this analysis using FEM was, by all means, fulfilled. From the implemented analytical contact models was finally chosen the most suitable one - contact model Passaribu \& Shipper. This model is going to be used for the time-effective solution of contact problems of real rough surfaces of machinery parts. According to our expectation it was proven that the detailed solution of contact problems using FEM in combination with MBS is not applicable for online solution of similar contact tasks. The reason for the unsuitability of this application lies mainly in its high demands regarding the time-efficiency.

\section{ACKNOWLEDGEMENT}

The research leading to these results has received funding from the Technology Agency of the Czech Republic, programme Competence Centres, project Josef Bozek Competence Centre for Automotive Industry, project No. TE01020020. Significant support has also been obtained from the Faculty of Mechanical Engineering of Brno University of Technology, project Fund of Science FME 2015, project No. FV 15-27.

\section{REFERENCES}

[1] Greenwood, J. \& Tripp, J. 1970. The contact of two nominally flat rough surfaces. ARCHIVE: Proceedings of the Institution of Mechanical Engineers 1847-1982 (vols 1-196), vol. 185, issue 1970, pp. 625-634.

[2] Stachowiak, G. 2014. Engineering tribology. $4^{\text {th }}$ ed. Oxford: Butterworth-Heinemann.

[3] Lagemann, V. 2000. Numerische Verfahren zur tribologischen Charakterisierung bearbeitungsbedingter rauher Oberflächen bei Mikrohydrodynamik und Mischreibung. Dissertation. Kassel: Univ.-Bibliothek.

[4] Pasaribu, H. \& Schipper, D. 2005. Application of a Deterministic Contact Model to Analyze the Contact of a Rough Surface Against a Flat Layered Surface. Journal of Tribology, vol. 127, issue 2, pp. 451-455. Available from: http://Tribology.asmedigitalcollection.asme.org/article. aspx?articleid=1467327. 